\title{
OBITUARY
}

\section{Jesus Santiago Moure (2.XI.1912 - 10.VII.2010)}

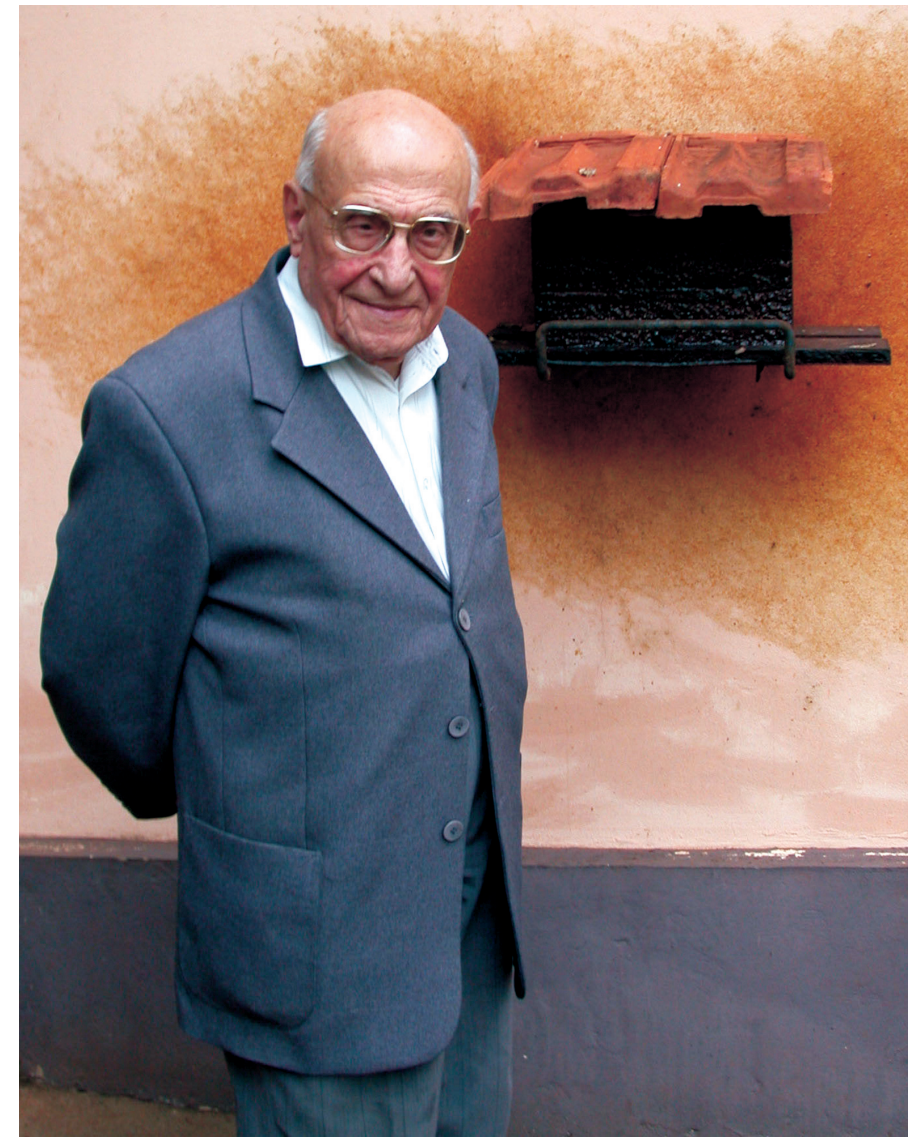

Jesus Santiago Moure, São Simão, SP, Brazil, September, 2002.

Jesus Santiago Moure was born on November $2^{\text {nd }}, 1912$, in Ribeirão Preto, São Paulo. He earned a degree in Philosophy (which included the Natural Sciences, Physics and Mathematics) from the Seminário Maior Claretiano, in Rio Claro (1929-1932), and then proceeded to study Theology at the Seminário Maior Claretiano, in Curitiba (1933-1936). In 1937, he moved to the city of São Paulo in order to finish his degree in Theology, and was ordained a priest there on May $23^{\text {rd }}, 1937$. During his stay in São Paulo, he became acquainted with Frederico Lane, from the Museu Paulista, who introduced him to insect taxonomy. The two collaborated on three publications dealing with curculionid beetles (Coleoptera). Additionally, following Lane's advice, father Moure took upon the task of studying the bee collection of the Museu Paulista. The decision to study bees opened up new horizons for him, and marked the beginning of his fruitful scientific career.
Paulista de Ribeirão Preto, nascido a 2 de novembro de 1912, Jesus Santiago Moure, formou-se em Filosofia, incluindo Ciências Naturais, Física e Matemática, pelo Seminário Maior Claretiano, em Rio Claro (1929-1933) e a seguir, cursou Teologia no Seminário Maior Claretiano, em Curitiba (19331936). Em 1937, permaneceu na cidade de São Paulo para concluir o curso de Teologia, tendo sido ordenado Sacerdote em 23 de maio de 1937, nesta mesma cidade. Durante sua estada em São Paulo, conheceu Frederico Lane do Museu Paulista, que o introduziu na taxonomia dos insetos. Em colaboração, os dois publicaram três artigos sobre espécies de Curculionidae (Coleoptera), e Lane sugeriu ao Padre Moure que iniciasse o estudo das abelhas da coleção depositada no Museu Paulista. Esta proposta para estudar abelhas, abriu novos horizontes e foi o início de uma carreira científica extremamente produtiva. 


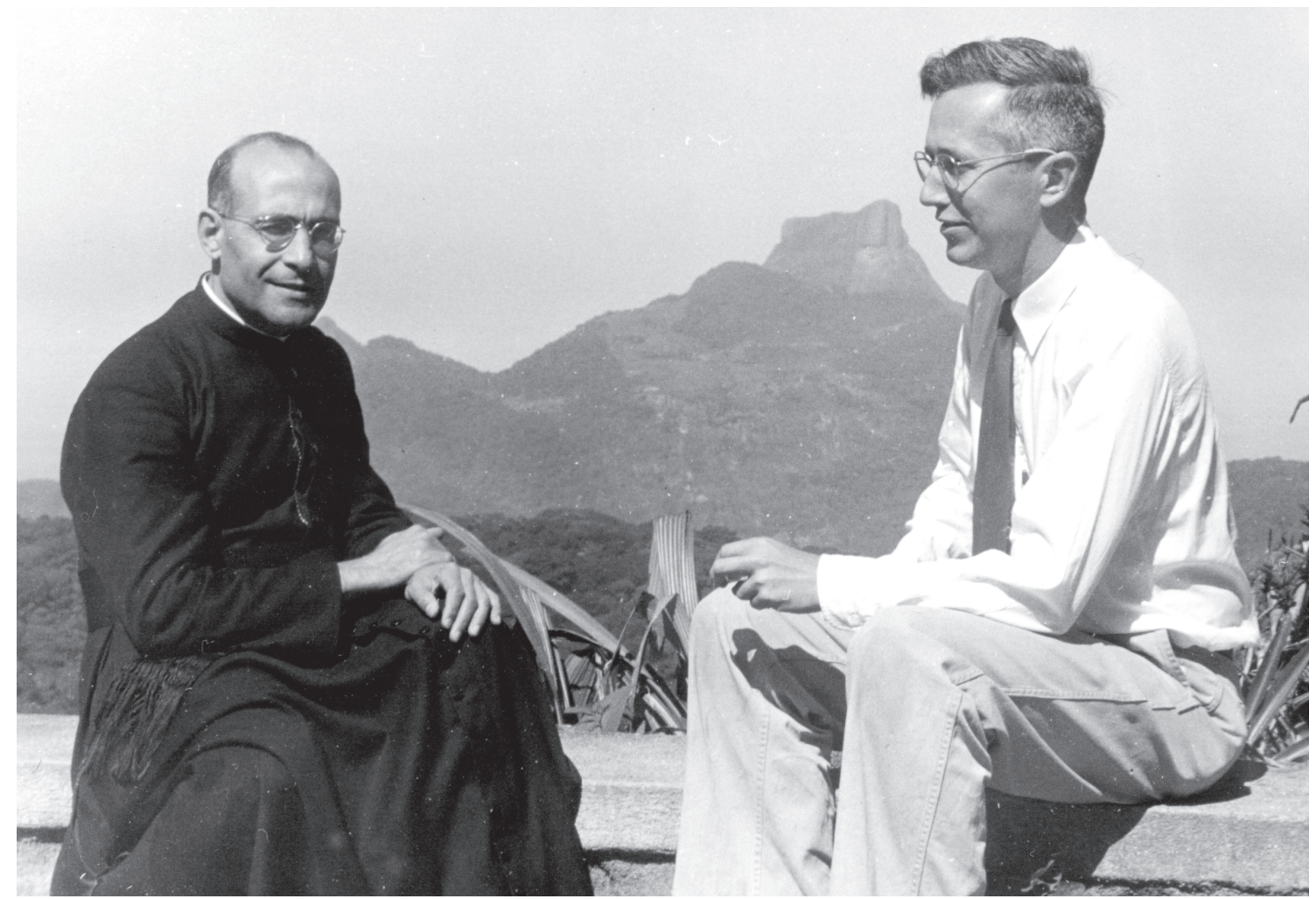

Moure and Michener, Rio de Janeiro, RJ, Brazil, July, 1955.

Upon his return to Curitiba in 1938, Moure became professor of Natural Sciences, Physics, Chemistry and Mathematics at the Seminário Claretiano and was soon involved in activities outside ecclesiastical circles. Due to his long-term friendship with José Loureiro Fernandes, dating back to the Círculo de Estudos Bandeirantes, Moure participated in the creation of the Faculty of Philosophy, Sciences and Letters, taking the cathedra of Zoology. A few years later (1946), following the requirements of the Ministry of Education, this Faculty was integrated with the Faculties of Medicine, Law and Engineering into the new University of Paraná.

At the invitation of José Loureiro, Moure joined the Museu Paranaense, becoming chair of the Zoology Division in 1939. In 1950 he participated in the restructuring of the University of Paraná, which then became a federal institution. From 1952 to 1954, Moure acted as Director of the Museu Paranaense. During this period, he purchased a large amount of bibliographic material, starting the first Zoology library of the Federal University of Paraná (UFPR), which later was partially returned to the Museu Paranaense.

Moure's first long trip outside of Brazil happened in 1956, when he traveled to the University of Kansas, Lawrence (USA) in the company of Charles D. Michener and his family. Michener was returning home after a sabbatical year in Curitiba,
Ao retornar para Curitiba, em 1938, Moure passa a lecionar Ciências Naturais, Física, Química e Matemática no Seminário Claretiano e prontamente envolve-se também em atividades fora dos círculos eclesiásticos. Por sua amizade com José Loureiro Fernandes, dos tempos do Círculo de Estudos Bandeirantes, participa da fundação da Faculdade de Filosofia, Ciências e Letras, assumindo a cátedra de Zoologia. Essa Faculdade integrou-se com as demais - Medicina, Direito e Engenharia - para reformular, em 1946, a nova Universidade do Paraná, dentro dos moldes então exigidos pelo Ministério da Educação.

Também a convite de José Loureiro, Pe. Moure passa a integrar o Museu Paranaense onde assumiu a Direção da Divisão de Zoologia, em 1939. Em 1950 participou da reestruturação da Universidade do Paraná, que foi então federalizada, e logo a seguir foi Diretor do Museu Paranaense, de 1952 a 1954, época em que comprou vasto material bibliográfico iniciando a primeira biblioteca da Zoologia, que posteriormente, foi parcialmente reintegrada ao Museu Paranaense.

Sua primeira grande viagem ao exterior foi em meados de 1956, à Universidade de Kansas, Lawrence, nos Estados Unidos, juntamente com Charles D. Michener e seus familiares, que retornavam após um ano de permanência e muito trabalho 
where he had worked in collaboration with Moure. During his six-month stay in Lawrence, Moure worked on the bee collection and took Robert R. Sokal' Biometry class, witnessing the birth of numerical taxonomy. In the following months, he travelled within the US to study bee collections in various universities and museums. On his return to Lawrence in June, 1957, he obtained, through Michener, a grant from the US National Science Foundation for a one year stay in Europe, beginning that August. According to his travel notes, this experience was an exceptional opportunity that greatly enriched his professional formation. While in Europe, Moure visited entomological collections in several countries.

Moure continued to study type specimens deposited in European and North American institutions during the 1960's and through the 1970's. However, his lifelong dream to study the type material housed in the Museum für Naturkunde (Berlin) only materialized more than two decades later. During June and August of 1996, accompanied by Olaf H. H. Mielke, Moure was finally able visit that museum. He returned to Germany the following year, and again in 1999. As a result of all his travels, Moure compiled a total of 1,700 manuscript pages containing detailed notes on the types of Neotropical bees.

Moure published more than 220 articles, mainly on Neotropical bees. Collectively, he proposed a total of 484 species-group names, 219 genus-group names and 17 familygroup names. His scientific production includes three books, two in collaboration with Paul D. Hurd Jr., and the most recent "Catalogue of Bees in the Neotropical Region" (2007). The latter, organized by Moure, Urban and Melo, assembles all the information previously summoned by Moure, including his handwritten notes and the cards typed during his first visit to Michener, with subsequent updates. This work, cataloguing a total of 5029 valid species names, received the "Alexandre Rodrigues Ferreira Prize" (Brazilian Society of Zoology) in 2010.

Moure organized the Entomology Graduate Program of the Zoology Department, UFPR (offering M.Sc. and Ph.D. degrees). Overall, he advised over 11 Ph.D. dissertations and 35 Master theses in the Entomology Program. Furthermore, Moure was involved in the foundation of the National Council for Scientific and Technological Development - CNPq and CAPES, the two main federal research funding agencies in Brazil; he was also a co-founder of the Brazilian Society of Entomology - SBE (1937), Brazilian Society for the Advancement of Science - SBPC (1948) and Brazilian Society of Zoology -SBZ (1978).

In 1961, Moure was admitted to the Brazilian Academy of Sciences, from which he received the "Costa Lima Prize" (1970). Throughout his career, Moure received numerous other prizes and honorific titles, including the two most prestigious titles granted to Brazilian scientists by the federal government: "Comendador da Ordem Nacional do Mérito Científico" (1995) and "Grã-Cruz da Ordem Nacional do Mérito Científico" (1998). He also received an honorary doctorate degree (1982) and the title of emeritus professor (1986) from the Federal University em colaboração, em Curitiba. Permaneceu em Lawrence por seis meses, estudando a coleção de abelhas, tendo também participado do curso de Estatística ministrado por Robert R. Sokal e presenciado o desenvolvimento inicial da taxonomia numérica. A seguir estudou as coleções de outras Universidades norte-americanas, até junho de 1957. Ao voltar para Kansas recebeu um auxílio da National Science Foundation, obtido por Michener, para estada de um ano na Europa, a partir de agosto de 1957, uma viagem que foi "excepcional para sua formação", segundo suas anotações. Na Europa, visitou as coleções entomológicas dos museus de diversos países e prosseguiu com as anotações.

Em viagens subseqüentes, nas décadas de 1960 a 1970, deu continuidade ao estudo dos tipos, tanto na Europa como nos Estados Unidos. Porém, faltava ainda examinar as abelhas da coleção do Museum für Naturkunde, em Berlim. Acompanhado por Olaf H.H. Mielke, em junho e agosto de 1996, realizou seu sonho. Voltou à Alemanha no ano seguinte e depois em 1999. Como resultado de suas viagens, produziu 1.700 páginas manuscritas com anotações sobre os tipos das abelhas neotropicais.

Publicou mais de 220 artigos, dando a conhecer principalmente a riqueza de espécies da região neotropical, tendo proposto um total de 484 nomes do grupo-espécie, 218 do grupo-gênero e 17 do grupo-família. Na sua produção constam três livros, dois deles em colaboração com Paul D. Hurd Jr e o mais recente, em 2007, "Catalogue of Bees in the Neotropical Region", organizado por Moure, Urban e Melo, reunindo todas as informações catalográficas desde suas primeiras notas manuscritas até os cartões que foram datilografados quando da sua primeira visita ao Michener e atualizados posteriormente. Esta obra cataloga um total de 5029 nomes válidos para espécies viventes e recebeu, em 2010, o "Prêmio Alexandre Rodrigues Ferreira", concedido pela Sociedade Brasileira de Zoologia.

Organizou o Curso de Pós-Graduação em Entomologia do Departamento de Zoologia da UFPR, a nível de Mestrado e Doutorado, tendo sido Professor orientador de 11 teses de Doutorado e 35 dissertações de Mestrado. Envolveu-se na fundação do CNPq e da Capes, principais órgãos relacionados à pesquisa e à ciência do Brasil; também da fundação da Sociedade Brasileira de Entomologia - SBE (1937), Sociedade Brasileira para o Progresso da Ciência-SBPC (1948) e da Sociedade Brasileira de Zoologia - SBZ (1978).

Em 1961, ingressou na Academia Brasileira de Ciências, da qual recebeu o "Prêmio Costa Lima", em 1970. Numerosos outros prêmios e homenagens foram a ele concedidos, destacando-se as mais elevadas condecorações concedidas pelo governo brasileiro a cientistas: "Comendador da Ordem Nacional do Mérito Científico" (1995) e "Grã-Cruz da Ordem Nacional do Mérito Científico" (1998). A Universidade Federal do Paraná conferiu-lhe os títulos de Doutor Honoris Causa (1982) e de Professor Emérito (1986). Desde 1982, a coleção de 
of Paraná, and had the insect collection of the Zoology department, now the "Coleção de Entomologia Prof. Pe. Jesus Santiago Moure" (DZUP), named after him (1982). More recently, during the $55^{\text {th }}$ anniversary of CNPq (2006), Moure was awarded the title of emeritus researcher.

Father Jesus Santiago Moure, a national science icon, passed away on the $10^{\text {th }}$ of July, 2010, at the age 97, in the house of the Claretian Missionaries in Batatais, São Paulo. insetos do Departamento de Zoologia da UFPR foi denominada "Coleção de Entomologia Prof. Pe. Jesus Santiago Moure". Em 2006, recebeu o Diploma de Pesquisador Emérito como parte das comemorações dos 55 anos do CNPq.

Pe. Jesus Santiago Moure, ícone da pesquisa científica no país, faleceu no dia 10 de julho de 2010, aos 97 anos de idade, na residência dos Missionários Claretianos em Batatais, São Paulo.

\section{Gabriel A. R. Melo \& Danúncia Urban}

Departamento de Zoologia, Universidade Federal do Paraná. Caixa Postal 19020, 81531-980 Curitiba, PR, Brazil.

Submitted: 10.VIII.2010; Accepted: 18.VIII.2010.

Editorial responsibility: Walter A.P. Boeger 